\title{
Gender and the translation of audiovisual non-profit advertising
}

\author{
Montse Corrius Gimbert ${ }^{1}$ \\ University of Vic-Central University of Catalonia
}

Marcella De Marco

London Metropolitan University

\author{
Eva Espasa Borrás \\ University of Vic-Central University of Catalonia
}

\begin{abstract}
This paper aims to explore to what extent students enrolled on Translation and on Advertising courses are gender aware, i.e. whether they perceive that the decisions they take when translating or creating non-profit advertisements which present gender-related concerns may have an impact on the social perception of gender. Three groups of students of different levels (undergraduate versus postgraduate) and belonging to two different universities (University of Vic - Central University of Catalonia - Spain, and London Metropolitan University - UK) come under scrutiny. Drawing on previous stages of the study, the authors intend to examine how it is possible to address ethical issues in students' curricula, to what extent gender awareness guides students choices when they work with non-profit adverts as opposed to commercial ones, and whether professional priorities and gender perspectives are compatible. A set of non-profit advertisements analysed and translated by the students and two Likert-type questionnaires have been used for this purpose. In addressing these questions, this study intends to fill the existing gap between gender, translation and advertising-focused research.
\end{abstract}

Keywords: audiovisual translation, advertising, non-profit advertising, gender awareness

1 Corresponding author - University of VIC-Central University of Catalonia, Department of Communication, Sagrada Familia 7, 08500 Vic (Spain).

Email: montse.corrius@uvic.cat 


\section{RESUMEN}

Este artículo se propone explorar hasta qué punto el alumnado universitario de traducción e interpretación muestra conciencia de género, es decir, percibe que las decisiones tomadas al traducir o crear anuncios solidarios en los que se abordan cuestiones de género puede tener impacto en la percepción social sobre el género. Se estudian tres grupos de estudiantes de distintos niveles (grado y posgrado) y de dos universidades distintas (Universidad de Vic - Universidad Central de Catalunya y London Metropolitan University). Partiendo de las fases previas de un estudio más amplio, las autoras se proponen examinar cómo es posible tratar cuestiones éticas en el currículo del alumnado; hasta qué punto la conciencia de género guía las elecciones del alumnado cuando trabaja con anuncios solidarios en contraste con publicidad comercial, y si las prioridades profesionales y las perspectivas de género son compatibles. Para este propósito, se usó un conjunto de anuncios solidarios, que fueron traducidos y analizados por el alumnado, y dos cuestionarios de escala tipo Likert. Al abordar estas cuestiones, este estudio intenta explorar los vacíos existentes entre las investigaciones sobre género, traducción y publicidad.

Palabras clave: traducción audiovisual, publicidad, anuncios solidarios, conciencia de género

\section{Introduction}

This paper presents an interdisciplinary and interuniversity study in which we examine students' level of gender awareness in the analysis and translation of audiovisual non-profit advertising. Our ultimate aim is to explore whether our students are conscious of the consequences that their decisions regarding gender (either devising or translating a non-profit advertisement) may have on the response to gender as represented on the screen. We look at the work performed by students of Advertising and of Translation, both at undergraduate and postgraduate level.

The institutions involved in this study are London Metropolitan University (MA in Translation) and the University of Vic-Central University of Catalonia (UVic-UCC) (Degree in Translation and Interpreting; Degree in Advertising and Public Relations). The study is a follow-up of the three previous phases. The first one explored students' attitudes toward gender issues in advertising across different settings (London, Media for All 4 Conference, 2011). The second phase examined the connections between feminist pedagogies and our courses on advertising translation (Bartrina \& Espasa, 2012). The third phase included the evaluation of gender awareness (Bartrina et al., 2012).

This research aims to analyze to what extent gender awareness guides students' choices in translating audiovisual non-profit advertising, and see if there are any differences in gender awareness across different settings (translation versus advertising students, undergraduate versus postgraduate). From previous phases 
mentioned above it can be inferred that the perception of responsibility in students of translation towards gender issues is different from that of students of advertising. Therefore, our initial hypothesis in this research is that this responsibility is also different when they are working with non-profit advertising. This research is also aimed at making a contribution to the understanding of gender construction within and through the analysis and translation of non-profit advertising. This study also intends to build bridges between research on translation, gender, and non-profit advertising. In doing so, it addresses the challenges posed by the increasingly interdisciplinary nature of current research developed in Translation Studies (De Marco, 2016).

It is a fact that non-profit organizations (NPOs) have increased in the last three decades and they have become an important part of our modern societies and economies. According to Pope et al. (2013), the jobs in the non-profit sector represent $11 \%$ of the total workforce in this country, and since the beginning of the 21 th century they have grown faster than those in the for-profit sector (Blizor, 2007). However, this tendency has not had an influence on the advertising industry in so far as it has kept on investing in the for-profit sector rather than in the non-profit one (Alvarado López, 2012). It is worth mentioning, though, that in the last 100 years the advertising industry has produced numerous messages with a public or social interest in particular and sporadic causes, but it is not until the end of the Second World War when we can really talk about non-profit advertising. International organizations, environmental foundations, non-governmental organizations and institutions devoted to the coordination and diffusion of advertising, such as the Ad Council in the United States, appeared at that moment (Alvarado López, 2012). The first non-profit advertising campaigns were very simple and direct: they focused on the social problem rather than on persuasion. Thus, the rhetoric was straightforward, and the linguistic resources were very basic. But, as advertising about social issues increased, the audience got used to the new languages and it became necessary to use more rhetorical devices. As a result, a language distant from the one used in the for-profit sector emerged. During this process, creative ideas became more mature, and this was possible due to the social advertising culture developed by the different audiences. At the same time, the well-established strategies in non-profit advertising, namely emotional strategies, became common to the for-profit advertising. Although non-profit campaigns have had their own development, evolution and problems -different from commercial campaignsfrontiers are now blurring between non-profit and for-profit advertising (Nos Aldás, 2007).

According to Benet (2003), the main differences between the messages in for-profit (FPA) and non-profit advertising (NPA) are the following: the messages in FPA (i) refer 
to (close) goods, (ii) show a fictitious world, and (iii) promise happiness and satisfaction; whereas those in NPA (i) refer to people and not well-known matters, (ii) describe a dramatic reality, and (iii) unveil crudity, sorrow, suffering and injustice. For Álvarez Ruiz (2003), for-profit advertising seeks to create an immediate influence on people's behaviour to invite prompt action (to buy a product or use a service), whereas non-profit advertising is a longer and deeper process, because it seeks to modify beliefs, ideologies and attitude in a long term and also to affect behaviour but in an altruistic, non-self-oriented manner.

Gómez Ferri (2003) introduces a new concept: "Charity globalisation". He states that the increasing interconnection of people and places nowadays, as a result of the advances in communication, information, technology and transport, has given rise to what he calls "charity globalisation", that is, two or more worlds getting in touch and communicating, so charity takes on an international dimension and goes beyond the local and national boundaries. In this sense, the impact of cultural differences should be taken into consideration in so far as people from different societies, who do not share the same beliefs and values, may not have an identical concept of charity. Thus, from a global non-profit advertising point of view, these differences must be known and understood and the cultural context of the target audience must be well acquainted: "If you want to reach consumers in different parts of the world, speak to them in a way they understand" (De Mooij, 2014a, p. 361).

Some non-profit advertising campaigns are intended to help, sensitize or persuade either the Other or the people who can generate the necessary resources (material, human, cognitive or moral) to come to somebody's aid. When we talk about the Other we refer to the usual recipients of non-profit campaigns: i. e. drug addicts, alcoholics, ill people, elderly, battered women, orphans, handicapped people, immigrants, deprived people, passers-by, refugees. On occasion, the campaign will be clearly aimed at the Other; in other cases, We are the target, and the Others are the ones who motivate the campaigns and become omnipresent in the messages.

\section{The gender variable in non-profit advertising}

In this research, we draw on the notions of individualistic versus collective cultures, and masculine versus feminine cultures, as defined by Hofstede (2001) and developed by De Mooij (2014b, pp. 193-194) in connection with advertising:

In individualistic cultures, identity is in the person, and people want to differentiate themselves from others. In collectivistic cultures, identity is based in the social network to which one belongs. In individualistic cultures people are "I" conscious and express private opinions. [...] In collectivistic 
cultures people are "we" conscious-their identity is based on the social system. [...] In individualistic cultures people read more books and use more e-mail and other written means of communication. It explains differences in Internet buying and differences in the type of activities of people on the Internet such as e-mailing or blogging and use of social media, the latter being used more in collectivistic cultures than in individualistic cultures.

The masculinity-femininity cultural dimension of countries was described by Hofstede (2001) and it is based on how countries embrace gender roles, and how they view masculine (assertiveness) versus feminine (nurturing) values. These are seen as learned styles of interpersonal interaction, and "should not be taken to imply that men always actually behave in a more masculine manner than do women or that women behave in more feminine ways than do men" (Hofstede, 2001, p. 284).

\footnotetext{
Hofstede's dimension masculinity-femininity is a complex dimension as it measures the degree of assertiveness or achievement orientation versus quality of life as well as the degree of role differentiation versus overlapping roles of males and females (De Mooij, 2014b, p.197).
}

The research carried out on the interference of gender in non-profit advertising is mainly devoted to the reception of advertising texts. Literature in the field shows that women consumers tend to have a more collectivist orientation, are more concerned about altruism and, accordingly, tend to donate more money to NPOs than men. However, some studies have challenged previous assumptions and they have drawn a more complicated cartography.

For instance, Nelson et al. (2006) challenged the views that women across cultures prefer altruistic appeals in NPO adverts and that men prefer egoistic appeals. The authors worked with two "masculine" cultures (Canada and United States) and two "feminine" cultures (Denmark and Norway):

In two experiments, we showed that men and women in individualist cultures respond differently to value-expressive charity appeals based on sex-role ideology as predicted by the masculinity-femininity dimension. Thus, not all individuals in individualistic cultures resonated with the selffocused appeal. Neither did all women in these cultures respond favourably to the other-focused appeal (Nelson et al., 2006, p. 46).

Thus, this cross-cultural study found that the cultural dimension of masculinityfemininity impacts the effectiveness of non-profit advertisements.

Gender roles are an important factor when Non-profit Organization Advertising uses altruistic-value messages (that indicate that donations help the others) or egoistic 
ones (when donations have advantages for the donors themselves): men and women receive them differently. It has been said that women tend to value altruistic messages while men tend to value selfish messages, which make up their selfesteem. However, there have also been many researches that have challenged this. Chang \& Lee (2009) found that the interaction effect of gender differences and nonprofit advertising can be attributed to and are moderated by different degrees of self-referencing. In their words:

When individuals perceive a NPO as having a higher level of selfreferencing, the effects of the "I" of the beholder (i.e., congruence between the gender and the message theme) may facilitate advertising persuasion. Conversely, when facing a NPO with a lower level of self-referencing, the "I" may be determined by how a charity message is framed (egoistic vs. altruistic). In short, incongruity between the gender and message theme lead to higher advertising effectiveness (Chang \& Lee, 2009, p. 748).

NPOs advertisements express values: the benefits they sell are intangible. Two ways of influencing the target audience of the non-profit advertisement are through communicating the successes of the NPO or emphasizing the donors' role in the success. Laufer et al. (2010, p. 1330) conducted a research with the conclusion that women will be more likely to donate in response to an appeal that gives credit to donors, whereas men will be more likely to donate in response to an appeal that credits the effectiveness of the charitable organization. They even recommend NPOs to develop separate advertisements targeting male and female donors in order to maximize their effectiveness.

We would like to end this section with a brief reference to the representation of children in non-profit advertisements, since this representation usually intersects with the representation of gender in NPOs.

Images of children are particularly powerful in generating all kinds of emotional reactions in all kinds of advertising. In NPOs advertising images of poor children are used very often. Burt \& Strongman (2005) have shown that images of children that generate negative emotions provoke larger monetary donations. Two of the commercials of our study, "One water" (2010) and "What will you feel" (2008), use images of children.

The influential critical development psychologist Burman (1994) has suggested that showing images of suffering children, connoting those qualities of dependence and powerlessness that constitute the defining characteristics of childhood, results in reassuring adult capacities. The individual starving child is seen as the general representation of hunger. This representation is connected to an idealised representation of Western models of childhood. In her words: 


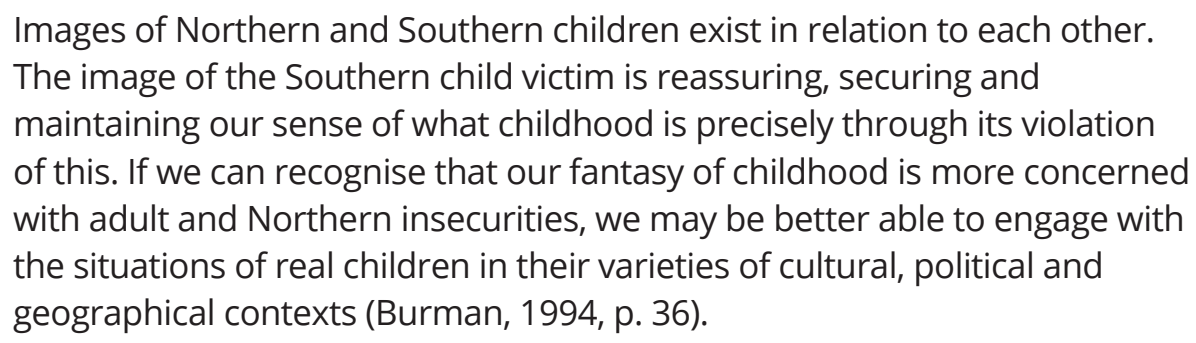

In this sense, Richards (2004) has studied the representation of the Third World by NPOs advertisements and their influence on British public opinion. He asks for a new approach to charity advertisements that increases public education throughout the partnership with the news media and the aim of Third World self-sufficiency.

\section{The study: methodology}

\subsection{Subjects}

Three groups of students were involved in this study:

-Group 1: 10 undergraduate students of Advertising and Public Relations at UVic-UCC

-Group 2: 10 postgraduate students of the MA in translation at London Metropolitan University

-Group 3: 16 undergraduate students of Translation and Interpreting at UVic-UCC

The students belonging to these groups were not selected on the grounds of specific cultural awareness or expectations in relation to gender issues, but rather on the fact that they were enrolled on courses of advertising and/or audiovisual translation, both taking some lessons on the translation of advertising. The lecturers were interested in exploring their level of gender awareness developed as a result of their personal experiences and backgrounds, rather than of having been previously exposed to studies or work contexts which had enhanced their commitment to gender equality principles. While the students of Group 1 and Group 3 were in their 20 s and more homogenous in terms of ethnicity (Catalan/Spanish), the students of Group 2 were older (in their 30s) and ethnically more varied (see below).

The teaching context of Group 1 was the degree in Advertising and Public Relations at UVic-UCC. The degree includes three courses in English since it is one of the main languages used in the advertising and public relations sectors and students are expected to learn the academic and professional use of the language. This study was carried out in the first English course, which is addressed to first year students, and carries 6 ECTS credits (3.5 hours per week, 15 weeks in the spring term). 
The teaching context of Group 2 was the MA in Translation at London Metropolitan University, which offers twenty-four language pathways and is therefore addressed to students coming from very different linguistic and cultural backgrounds. The majority are non-English native speakers. The students who took part in this study were 1 Brazilian, 1 Greek, 3 Italians, 2 French, 1 Japanese, 1 Polish and 1 Russian. The context of this study is a twelve-week subtitling module corresponding to 10 ECTS credits. The syllabus of the subtitling module comprises technical, stylistic and translation-related issues inherent to this audiovisual translation mode.

The teaching context of Group 3 was the degree of Translation and Interpreting at UVic-UCC, where a course on the translation of advertisements and promotional texts has been offered since 1996. The course is addressed to 2 nd year students translating from English into Catalan or into Spanish, and carries 3 ECTS credits (2 hours per week, 15 weeks in the spring term). The syllabus covers translation of print advertisements (5 weeks), commercials (5 weeks) and illustrated texts (5 weeks).

\subsection{Materials}

In an earlier phase of this research, we had worked with three commercial advertisements: 1) L'Oreal Jennifer Aniston, 2) L'Oreal Kerry Washington, and 3) Miller Second Unmanly Thing (see transcripts in Appendix 1); whereas in the present phase we added three non-profit advertisements to be compared with the commercial ones: 1) Domestic Violence, 2) One Water, and 3) What will you feel. In both phases the set of advertisements were translated and commented on by all groups in the study and the students answered two questionnaires.

These non-profit advertisements are transcribed here and will be commented on below.

\section{Domestic violence}

The advertisement below shows a peculiar marriage ceremony, in which the traditional vows of bride and bridegroom have been replaced by the bride's promises that will allow domestic violence. 
http://www.youtube.com/watch?v=MyD1IK8qr14

\begin{tabular}{|c|c|}
\hline $\begin{array}{l}\text { Transcript } \\
\text { Domestic Violence }\end{array}$ & \\
\hline Bride: & $\begin{array}{l}\text { I vow to make excuses when you } \\
\text { humiliate me in public, to forsake my } \\
\text { friends and family, when you isolate } \\
\text { me and to value myself less when you } \\
\text { belittle me. I vow to blame myself } \\
\text { when you hit me, and to fear for my } \\
\text { safety and the safety of our children } \\
\text { till death do us part. }\end{array}$ \\
\hline Off-screen voice: & $\begin{array}{l}\text { Don't ignore domestic abuse. Speak } \\
\text { now. The Family Justice Center is a } \\
\text { place of safety. }\end{array}$ \\
\hline
\end{tabular}

Transcript 'Domestic Violence'.

What Will You Feel

http://www.youtube.com/watch?v=cmFW-P-ZyWs

\begin{tabular}{|c|c|}
\hline $\begin{array}{l}\text { Transcript } \\
\text { What will you feel }\end{array}$ & \\
\hline Child 1 [girl]: & What is hope? \\
\hline Man: & $\begin{array}{l}\text { Hope is when a family who had to walk miles } \\
\text { for water, now has it pumped to their village. }\end{array}$ \\
\hline Child 2 [boy]: & What is joy? \\
\hline Woman 1: & $\begin{array}{l}\text { Joy is when a young boy from the slums goes } \\
\text { to school for the first time. }\end{array}$ \\
\hline Child [boy] 3: & What is pride? \\
\hline Woman 2: & $\begin{array}{l}\text { Pride is when a child you help to read and } \\
\text { write sends you a letter to say thank you. }\end{array}$ \\
\hline $\begin{array}{l}\text { Off-screen voice } \\
\text { [woman]: }\end{array}$ & $\begin{array}{l}\text { You can become a World Vision child sponsor } \\
\text { for just } 60 p \text { a day. What you give means so } \\
\text { much to the child and their community. But } \\
\text { what you feel in return is priceless. What will } \\
\text { you feel when you sponsor a child with World } \\
\text { Vision? Call World Vision now on } 0800501010 \\
\text { or visit sponsor.org }\end{array}$ \\
\hline
\end{tabular}

Transcript 'What will you feel'.

In this advertisement, men and women comment on the benefits of sponsoring children, both for the children involved and for the sponsors. The ad shows images and voices of children, both girls and boys, in juxtaposition with the voices and images of men and women sponsors. From the images in the ad, we can perceive a 
general search for balance as regards gender, ethnicity and ages of the persons portrayed, although boys appear in a prominent position, as is reflected in the translations.

One Water

http://www.youtube.com/watch?v=P3vuDIpDM2E

\begin{tabular}{ll}
\hline $\begin{array}{l}\text { Transcript } \\
\text { One Water }\end{array}$ & \\
\hline DAVID TENNANT: & $\begin{array}{l}\text { Did you know that more than one billion } \\
\text { people in the world have no access to clean } \\
\text { water? } \\
\text { That each year at least two million people die }\end{array}$ \\
CLAIRE GOOSE: & $\begin{array}{l}\text { from drinking contaminated water? } \\
\text { IAN KELSEY: }\end{array}$ \\
to collect water?
\end{tabular}

Transcript 'One Water'.

For the purpose of this study, two questionnaires were used. The first questionnaire, which was used in previous phases of the study, is aimed at testing their approach to analysing/translating advertisements in general and the impact that this approach may have on the transmission of gender stereotypes. The second questionnaire, which was specifically devised for this study, is more focused on exploring whether students adopt a different approach when dealing with the translation of profit and non-profit advertisements. The results are compiled in the collective tables below, where there is one table for each statement. In this research, students were asked to answer a five-point Likert-scale questionnaire, since this instrument has proved 
useful when assessing attitudes towards gender in learning contexts (see, e.g., García Pérez et al., 2010; Rebollo-Catalán, García Pérez, Piedra, \& Vega, 2011).

\subsection{Analysis of the questionnaires}

This section presents the evaluation of the replies to the two questionnaires given by the students of the three groups involved in the study. The answers have been analysed from a quantitative and a qualitative point of view.

\section{QUESTIONNAIRE 1}

Express your agreement/disagreement with the following statements

(1: I disagree completely with this statement; 5: I completely agree with this statement)

a) Advertising reproduces gender stereotypes (i.e. generalizations which potentially lead to sexist, racial, employment discrimination).

\begin{tabular}{llll}
\hline $\begin{array}{l}\text { Level of } \\
\text { agreement }\end{array}$ & $\begin{array}{l}\text { Group1 BA } \\
\text { Advertising } \\
\text { UVic-UCC } \\
\text { (out of 10) }\end{array}$ & $\begin{array}{l}\text { Group 2 MA } \\
\text { Translation } \\
\text { London Met. } \\
\text { (out of 10) }\end{array}$ & $\begin{array}{l}\text { Group 3 BA } \\
\text { Translation } \\
\text { UVic-UCC } \\
\text { (out of 16) }\end{array}$ \\
\hline 1 & $0=0 \%$ & $2=20 \%$ & $0=0 \%$ \\
\hline 2 & $1=10 \%$ & $1=10 \%$ & $1=6 \%$ \\
\hline 3 & $3=30 \%$ & $3=30 \%$ & $0=0 \%$ \\
\hline 5 & $\mathbf{5 = 5 0 \%}$ & $\mathbf{4 = 4 0 \%}$ & $5=31 \%$ \\
\hline
\end{tabular}

Table 1. Results Questionnaire 1- a).

Although there is overall agreement with this statement, in fact only the group from the undergraduates in Translation seem to agree strongly, whereas there is more variation in the other two groups and even a total disagreement on the part of $20 \%$ of the Master's students. This divergence may be due to the wider ethnic spectrum characterizing Group 2. People who come from different cultural backgrounds tend to have different perceptions of gender because they have been exposed to different kinds of representation of gender in their home countries. As a consequence, it is very likely that they have divergent opinions about the extent to which advertisements filter gender stereotypes. In contrast, Group 3 is a fairly culturally homogeneous group, of native Spanish and Catalan students of 
translation, and their academic context favours reflection on gender issues. As far as Group 1 is concerned, we may say that gender stereotypes have repeatedly been used in advertising, thus these students are the ones who most agree with the statement.

b) My professional practice may contribute to perpetuating gender stereotypes in advertising.

\begin{tabular}{llll}
\hline $\begin{array}{l}\text { Level of } \\
\text { agreement }\end{array}$ & $\begin{array}{l}\text { Group1 BA } \\
\text { Advertising } \\
\text { UVic-UCC } \\
\text { (out of 10) }\end{array}$ & $\begin{array}{l}\text { Group 2 MA } \\
\text { Translation } \\
\text { London Met. } \\
\text { (out of 10) }\end{array}$ & $\begin{array}{l}\text { Group 3 BA } \\
\text { Translation } \\
\text { UVic-UCC } \\
\text { (out of 16) }\end{array}$ \\
\hline 1 & $1=10 \%$ & $2=20 \%$ & $1=6 \%$ \\
\hline 2 & $0=0 \%$ & $2=20 \%$ & $2=12 \%$ \\
\hline 3 & $\mathbf{5 = 5 0 \%}$ & $\mathbf{4 = 4 0 \%}$ & $4=25 \%$ \\
\hline 5 & $2=20 \%$ & $2=20 \%$ & $3=19 \%$ \\
\hline
\end{tabular}

Table 2. Results Questionnaire 1-b).

Interestingly, the answers are varied in this case as only in Group 3 there is a majority of students who totally agree with this statement. The students from the other two groups show a mild level of agreement and there is even a minority in Groups 1 and 2 who do not think that their professional practice may contribute to mediating gender stereotypes. It is possible to explain this discrepancy by making reference to the curricular and extra-curricular activities to which students are exposed to. The Faculty of Education Translation and Humanities of the UVic-UCC is often involved in gender equality initiatives as gender concerns are part of the curriculum at postgraduate level. It may be that some of the students of Group 3 took part in some of these initiatives; therefore, they had an opportunity to reflect upon gender concerns in the workplace before they were offered this questionnaire. This is not the case for the other two groups, who most probably were not exposed to similar opportunities.

c) In my profession I have responsibility over whether gender stereotypes are transmitted. 


\begin{tabular}{llll}
\hline $\begin{array}{l}\text { Level of } \\
\text { agreement }\end{array}$ & $\begin{array}{l}\text { Group1 BA } \\
\text { Advertising } \\
\text { UVic-UCC } \\
\text { (out of 10) }\end{array}$ & $\begin{array}{l}\text { Group 2 MA } \\
\text { Translation } \\
\text { London Met. } \\
\text { (out of 10) }\end{array}$ & $\begin{array}{l}\text { Group 3 BA } \\
\text { Translation } \\
\text { UVic-UCC } \\
\text { (out of 16) }\end{array}$ \\
\hline 1 & $1=10 \%$ & $2=20 \%$ & $1=6 \%$ \\
\hline 2 & $0=0 \%$ & $\mathbf{3 = 3 0 \%}$ & $2=12 \%$ \\
\hline 3 & $3=30 \%$ & $1=10 \%$ & $\mathbf{7 = 4 4 \%}$ \\
\hline 5 & $\mathbf{5 = 5 0 \%}$ & $\mathbf{3 = 3 0 \%}$ & $3=19 \%$ \\
\hline
\end{tabular}

Table 3. Results Questionnaire 1-c).

Only advertising students seem to mostly agree about their professional responsibility in the transmission of gender stereotypes, but there is much variation across the groups with regard to this statement. Besides, it is interesting to notice a small, although relevant percentage (10\%) in the Master's group (Group 2), who completely agree with this statement. If students in Group 1 are the ones who most agree with the statement "advertising reproduces gender stereotypes" (see question "a") it is not surprising that these students also feel more responsible over the transmission of gender stereotypes. In fact, throughout history, gender stereotypes have been used by advertising professionals. The variations between the two translation groups (Group 2 and Group 3) may be attributed to the cultural heterogeneity of Group 2. Also, the fact that these are postgraduate students may influence their different perceptions of professional responsibility.

d) In my profession, gender priorities are as important as other professional priorities.

\begin{tabular}{llll}
\hline $\begin{array}{l}\text { Level of } \\
\text { agreement }\end{array}$ & $\begin{array}{l}\text { Group1 BA } \\
\text { Advertising } \\
\text { UVic-UCC } \\
\text { (out of 10) }\end{array}$ & $\begin{array}{l}\text { Group 2 MA } \\
\text { Translation } \\
\text { London Met. } \\
\text { (out of 10) }\end{array}$ & $\begin{array}{l}\text { Group 3 BA } \\
\text { Translation } \\
\text { UVic-UCC } \\
\text { (out of 16) }\end{array}$ \\
\hline 1 & $\mathbf{2 = 2 0 \%}$ & $0=0 \%$ & $1=6 \%$ \\
\hline 2 & $\mathbf{2 = 2 0 \%}$ & $1=10 \%$ & $2=12 \%$ \\
\hline 3 & $\mathbf{2 = 2 0 \%}$ & $1=10 \%$ & $6=38 \%$ \\
\hline 5 & $\mathbf{2 = 2 0 \%}$ & $\mathbf{7 = 7 0 \%}$ & $\mathbf{7 = 7 0 \%}$ \\
\hline
\end{tabular}

Table 4. Results Questionnaire 1- d).

In this situation it is the Master students' group who mostly think that gender plays a role as important as other professional priorities, followed by Group 3, Translation, 
whereas the opinions range over all levels of agreement/disagreement in Group 1.

e) Developing knowledge about gender issues during the educational years will help me develop my professional ethics.

\begin{tabular}{llll}
\hline $\begin{array}{l}\text { Level of } \\
\text { agreement }\end{array}$ & $\begin{array}{l}\text { Group1 BA } \\
\text { Advertising } \\
\text { UVic-UCC } \\
\text { (out of 10) }\end{array}$ & $\begin{array}{l}\text { Group 2 MA } \\
\text { Translation } \\
\text { London Met. } \\
\text { (out of 10) }\end{array}$ & $\begin{array}{l}\text { Group 3 BA } \\
\text { Translation } \\
\text { UVic-UCC } \\
\text { (out of 16) }\end{array}$ \\
\hline 1 & $1=10 \%$ & $0=0 \%$ & $0=0 \%$ \\
\hline 2 & $0=0 \%$ & $0=0 \%$ & $0=0 \%$ \\
\hline 3 & $1=10 \%$ & $2=20 \%$ & $1=6 \%$ \\
\hline 5 & $3=30 \%$ & $\mathbf{5 = 5 0 \%}$ & $7=44 \%$ \\
\hline
\end{tabular}

Table 5. Results Questionnaire 1-e).

It is important to stress that there is a polarity, among all groups, towards a strong or total agreement about the importance of developing awareness about gender issues in the educational years. This is indicative of the need to prioritise this when devising and revising the content and approach used in the teaching portfolio of advertising/translation courses.

f) Advertising should not use sexist language.

\begin{tabular}{llll}
\hline $\begin{array}{l}\text { Level of } \\
\text { agreement }\end{array}$ & $\begin{array}{l}\text { Group1 BA } \\
\text { Advertising } \\
\text { UVic-UCC } \\
\text { (out of 10) }\end{array}$ & $\begin{array}{l}\text { Group 2 MA } \\
\text { Translation } \\
\text { London Met. } \\
\text { (out of 10) }\end{array}$ & $\begin{array}{l}\text { Group 3 BA } \\
\text { Translation } \\
\text { UVic-UCC } \\
\text { (out of 16) }\end{array}$ \\
\hline 1 & $0=0 \%$ & $0=0 \%$ & $0=0 \%$ \\
\hline 2 & $0=0 \%$ & $1=10 \%$ & $2=12 \%$ \\
\hline 3 & $0=0 \%$ & $2=20 \%$ & $3=19 \%$ \\
\hline 5 & $0=0 \%$ & $\mathbf{4 = 4 0 \%}$ & $3=19 \%$ \\
\hline 5 & $\mathbf{1 0 = 1 0 0 \%}$ & $3=30 \%$ & $\mathbf{8 = 5 0 \%}$ \\
\hline
\end{tabular}

Table 6. Results Questionnaire 1-f).

Here no group totally disagrees with the statement and the great majority tend to a strong or a total agreement. This can be justified by the fact that all the students surveyed shared certain values in terms of gender-based discrimination and gender neutral use of language or behaviour. 
g) Advertising should not produce sexist commercials.

\begin{tabular}{llll}
\hline $\begin{array}{l}\text { Level of } \\
\text { agreement }\end{array}$ & $\begin{array}{l}\text { Group1 BA } \\
\text { Advertising } \\
\text { UVic-UCC } \\
\text { (out of } \mathbf{1 0})\end{array}$ & $\begin{array}{l}\text { Group 2 MA } \\
\text { Translation } \\
\text { London Met. } \\
\text { (out of 10) }\end{array}$ & $\begin{array}{l}\text { Group 3 BA } \\
\text { Translation } \\
\text { UVic-UCC } \\
\text { (out of } \mathbf{1 6} \text { ) }\end{array}$ \\
\hline 1 & $0=0 \%$ & $0=0 \%$ & $0=0 \%$ \\
\hline 2 & $1=10 \%$ & $1=10 \%$ & $1=6 \%$ \\
\hline 3 & $0=0 \%$ & $1=10 \%$ & $1=12 \%$ \\
\hline 5 & $1=10 \%$ & $3=30 \%$ & $5=31 \%$ \\
\hline
\end{tabular}

Table 7. Results Questionnaire 1-g).

Here too there is an overwhelming tendency to (strongly or totally) agree with the statement. Interestingly enough, Group 2, who had provided a more varied spectrum of answers with regard to statement 1 ("advertising reproduces gender stereotypes"), now seem more unanimous about the need not to reproduce sexism in advertisements, which might show that they feel responsible for changing this in their profession.

\section{QUESTIONNAIRE 2}

Express your agreement/disagreement with the following statements.

(1: I disagree completely with this statement; 5: I completely agree with this statement)

a) It is relevant for you to work on both commercial and non-profit advertising during your educational training

\begin{tabular}{llll}
\hline $\begin{array}{l}\text { Level of } \\
\text { agreement }\end{array}$ & $\begin{array}{l}\text { Group1 BA } \\
\text { Advertising } \\
\text { UVic-UCC } \\
\text { (out of 10) }\end{array}$ & $\begin{array}{l}\text { Group 2 MA } \\
\text { Translation } \\
\text { London Met. } \\
\text { (out of 6) }\end{array}$ & $\begin{array}{l}\text { Group 3 BA } \\
\text { Translation } \\
\text { UVic-UCC } \\
\text { (out of 16) }\end{array}$ \\
\hline 1 & $0=0 \%$ & $0=0 \%$ & $0=0 \%$ \\
\hline 2 & $0=0 \%$ & $0=0 \%$ & $0=0 \%$ \\
\hline
\end{tabular}

Table 8. Results Questionnaire 2- a).

26 people out of 10 answered the second questionnaire. 


\begin{tabular}{llll}
\hline $\begin{array}{l}\text { Level of } \\
\text { agreement }\end{array}$ & $\begin{array}{l}\text { Group1 BA } \\
\text { Advertising } \\
\text { UVic-UCC } \\
\text { (out of 10) }\end{array}$ & $\begin{array}{l}\text { Group 2 MA } \\
\text { Translation } \\
\text { London Met. } \\
\text { (out of } \mathbf{6})^{\mathbf{3}}\end{array}$ & $\begin{array}{l}\text { Group 3 BA } \\
\text { Translation } \\
\text { UVic-UCC } \\
\text { (out of 16) }\end{array}$ \\
\hline 3 & $2=20 \%$ & $0=0 \%$ & $1=6 \%$ \\
\hline 4 & $2=20 \%$ & $0=0 \%$ & $5=31 \%$ \\
\hline 5 & $\mathbf{6 = 6 0 \%}$ & $\mathbf{6 = 1 0 0 \%}$ & $\mathbf{1 0}=\mathbf{6 3 \%}$ \\
\hline
\end{tabular}

Table 8 (cont.). Results Questionnaire 2-a).

The answers provided show an overall strong or total agreement with the importance of working with both types of advertising. Besides, no group totally or partially disagrees. Non-profit advertising tends to present profound humanitarian or social messages, and therefore students who had not been previously exposed to them in an educational context, immediately appreciated the relevance of being faced with different challenges and may relate this to their previous knowledge of and empathy towards non-profit organizations.

b) When working on non-profit advertising you have to be more sensitive than when working on commercial advertising

\begin{tabular}{llll}
\hline $\begin{array}{l}\text { Level of } \\
\text { agreement }\end{array}$ & $\begin{array}{l}\text { Group1 BA } \\
\text { Advertising } \\
\text { UVic-UCC } \\
\text { (out of 10) }\end{array}$ & $\begin{array}{l}\text { Group 2 MA } \\
\text { Translation } \\
\text { London Met. } \\
\text { (out of 6) }\end{array}$ & $\begin{array}{l}\text { Group 3 BA } \\
\text { Translation } \\
\text { UVic-UCC } \\
\text { (out of 16) }\end{array}$ \\
\hline 1 & $2=20 \%$ & $1=16.6 \%$ & $0=0 \%$ \\
\hline 2 & $0=0 \%$ & $1=16.6 \%$ & $0=0 \%$ \\
\hline 3 & $\mathbf{5 = 5 0 \%}$ & $\mathbf{2 = 3 3 . 3 \%}$ & $3=19 \%$ \\
\hline 5 & $1=10 \%$ & $1=16.6 \%$ & $6=37 \%$ \\
\hline
\end{tabular}

Table 9. Results Questionnaire 2- b).

A range of levels of agreement/disagreement is displayed in this case, although it is worth pointing out that the undergraduates in Translation express a stronger opinion about the existence of different levels of sensitivity needed when working with profit or non-profit advertisements. The reason for this can be the same as the one ventured for the answer to question $b$ in Questionnaire1, i.e. the fact that the 
students of the different groups have been exposed to gender-equality activities to a different extent.

c) You have to approach your work in a different way when translating commercial or non-profit advertising

\begin{tabular}{llll}
\hline $\begin{array}{l}\text { Level of } \\
\text { agreement }\end{array}$ & $\begin{array}{l}\text { Group1 BA } \\
\text { Advertising } \\
\text { UVic-UCC } \\
\text { (out of 10) }\end{array}$ & $\begin{array}{l}\text { Group 2 MA } \\
\text { Translation } \\
\text { London Met. } \\
\text { (out of 6) }\end{array}$ & $\begin{array}{l}\text { Group 3 BA } \\
\text { Translation } \\
\text { UVic-UCC } \\
\text { (out of 16) }\end{array}$ \\
\hline 1 & $\mathbf{4 = 4 0 \%}$ & $0=0 \%$ & $4=25 \%$ \\
\hline 2 & $1=10 \%$ & $0=0 \%$ & $0=0 \%$ \\
\hline 3 & $2=20 \%$ & $2=33.3 \%$ & $1=6 \%$ \\
\hline 4 & $2=20 \%$ & $\mathbf{3 = 5 0 \%}$ & $3=19 \%$ \\
\hline 5 & $1=10 \%$ & $1=16.6 \%$ & $\mathbf{8 = 5 0 \%}$ \\
\hline
\end{tabular}

Table 10. Results Questionnaire 2-c).

If you have answered 2, 3, 4 or 5 to this statement, explain in what way 'different'. Use no more than 60 words.

With the exception of Group 1, who largely does not feel the need to approach commercial and NP adverts differently, the other groups express a more homogenous agreement with this. Nevertheless, it is interesting to notice the complete or partial disagreement with this statement in Group 2, as well as the lack of intermediate levels of agreement/disagreement in Group 3, where the opinions are split between the two extremes (25\% disagree completely, 69\% agrees mostly or totally). It is also important to comment upon the open answers given by those students who have expressed a limited or strong agreement. Excluding the few participants in Group 1 who think that the objectives and processes involved in the two kinds of advertising are the same and therefore they do not justify a significant change in the translation approach, most respondents of all groups associate the need to use a different approach to the context (i.e. NP advertising is more serious and therefore it is based on emotional principles), to the audience (i.e. NP advertising addresses a wider general public, therefore it needs to be simple and appeal to their emotions by using language carefully), and to the clients (i.e. the clients of NP adverts may have different requests - appealing to sensitivity - from the ones who commission the translation or the production of commercials).

d) Using two adjectives of your choice describe each of the adverts you have worked on

The first aspect which strikes our attention is the amount and variety of adjectives 
selected by the participants of Group 1 as compared to the other groups. This may be due to the fact that students enrolled on the Advertising and Public Relations course are more used to dissecting the content (both visual and verbal) of adverts than Translation students, who are more focused on the challenges they pose in view of the transfer of the message into another language. Therefore, the former are more prone to appraise the effectiveness of the overall message with a full range of adjectives. It is to be noted that, with regard to the first commercial (L'Oreal」Aniston), within Group 1 there is a prevalence of negative adjectives (e.g. dull, pathetic, heavy, ridiculous, not original, boring), whereas the other three groups tend to look at positive aspects (e.g. elegant, modern, appealing, sexy, funny, dynamic), although a few also identify traces of sexism. One student in Group 3 finds it "feminine" but s/he does not explain in what sense.

As for the commercial L'Oreal_K Washington, the opinions are more spread. Interestingly, the same participants who found the first commercial (L'Oreal」 Aniston) sexist also found this one sexist, but this opinion is counterbalanced by that of those who, within the same group and within the others, find it sensual, winning and promoting self-confidence.

The third commercial (Miller Lite_Second Unmanly Thing) gains more positive comments by all groups who overall find it funny, original and intriguing. It is worth stressing that while the adjectives provided by Group 1 reflect opinions about the advert's effectiveness, many adjectives given by the other groups involve genderrelated considerations (e.g. "funny but biased", "stereotyped", "sexist"). The fourth advert is Domestic Violence, about which the great majority of students of all groups provide positive adjectives in terms of the impact that this advert may have on people's emotions. Most of them find it stunning, very emotional, explicit, brave and clever. However, it is interesting to point out that one student in Group 2 finds it "outrageous" and another one in Group 3 "a bit offensive". It is not clear whether these students think it is outrageous and offensive to the female character who embodies the victims of domestic violence, or to the male character who supposedly uses violence and who is "ironically" challenged in this advert. Also for the other two NP advertisements (One Water and What Will you Feel?), which are not explicitly gender-related, the students' focus is on the emotional charge that they bring and the useful, sensitising message they convey. Only a minority finds them pretentious and repetitive.

\subsection{Analysis of the translations}

For brevity's sake, here we will only analyse the translations of non-profit advertisements, which is the main focus of this stage in our research. We are going 
to analyse translations by the students in the three groups, in order to compare what the students say with what they do in practice, through translation decisionmaking.

In the Domestic violence commercial we can hear an off-screen voice saying: "don't ignore domestic abuse. Speak now". The expression "domestic abuse" is a term which coexists with other words, in different languages, to reflect the underlying concepts behind them, which include many forms and degrees of physical, psychological and sexual abuse (Cantera, 2002, p. 71). This diversity is reflected evenly in the translations provided by students in the three groups: for example, in Group 3, the term had been discussed before, in connection with the translation of other advertisements on the same issue. Students in Group 3 use comparable advertisements and campaigns in their target language, in order to identify the appropriate equivalent terminology. However, although they knew that "violència masclista" (male chauvinist violence) is the term currently used in Catalan legislation, in fact only one third used it. The expression "gender violence" has been used in different groups and language combinations. Although this has been critisized by different feminists on accounts that it invisibilizes women, the expression is present in Spanish legislation, campaigns and in the media, and this may explain its use in students' translations.

The variations present in the use of "domestic", versus other terms, can also be interpreted according to the audio visual information provided in the advertisement, which shows a contrast between the private and public dimensions of human relationships: a wedding can be seen as a public ratification of a private relationship. As can be seen from the interaction between the images and the words of the advert Domestic Violence, here the vows of love have been replaced by the vows of abuse, which are sanctioned by the audience attending the ceremony.

Group 1 - Advertising and Public Relations (UVic - UCC) (Catalan)

\begin{tabular}{lll}
\hline Domestic abuse & Back translation & Percentage \\
\hline violència domèstica & domestic violence & $50 \%$ \\
\hline abusos domèstics & domestic abuse & $16.6 \%$ \\
\hline mals & bad behaviour & $16.6 \%$ \\
comportaments & & \\
\hline & & $16.6 \%$ omission (no \\
& & translation of voice- \\
& & over narration \\
& & where this is said) \\
\hline
\end{tabular}

Table 11. Analysis of the translation of "Domestic Abuse". Group 1.

Here, the mistranslation "mals comportaments" (bad behavior) minimizes the 
impact of abuse.

Group 2 - Master London Metropolitan University (Several languages)

\begin{tabular}{lll}
\hline Domestic abuse & Back translation & Percentage \\
\hline $\begin{array}{l}\text { przemocy w rodzinie } \\
\text { (Polish) }\end{array}$ & $\begin{array}{l}\text { Violence in the } \\
\text { family }\end{array}$ & $20 \%$ \\
\hline abusi domestici (Italian) & Domestic abuse & $20 \%$ \\
\hline $\begin{array}{l}\text { Violência doméstica } \\
\text { (Brazilian Portuguese) }\end{array}$ & Domestic violence & $20 \%$ \\
\hline violence familiale (French) & Family violence & $20 \%$ \\
\hline
\end{tabular}

Table 12. Analysis of the translation of "Domestic Abuse". Group 2.

Group 3 - Translation and Interpreting (UVic - UCC) ${ }^{4}$

\begin{tabular}{lll}
\hline Domestic abuse & Back translation & Percentage \\
\hline $\begin{array}{l}\text { violència domèstica } \\
\text { (Catalan) / violencia } \\
\text { doméstica (Spanish) }\end{array}$ & Domestic violence & $31.26 \%$ \\
\hline $\begin{array}{l}\text { violència de gènere } \\
\text { (Catalan) / violencia de }\end{array}$ & Gender violence & $25 \%$ \\
género (Spanish) & & \\
\hline $\begin{array}{l}\text { violència masclista } \\
\text { (Catalan) / violencia }\end{array}$ & $\begin{array}{l}\text { Male chauvinist } \\
\text { machista (Spanish) }\end{array}$ & $12.50 \%$ \\
\hline Abuso doméstico (Spanish) & Domestic abuse & $31.26 \%$ \\
\hline
\end{tabular}

Table 13. Analysis of the translation of "Domestic Abuse". Group 3.

Another aspect is the widespread use of the generic masculine in the translation of "friends" and "children" in all groups by all students, which we can interpret from our teaching experience: students tend to generally agree with not using the generic masculine or the use of other forms of non-sexist language, but they only incorporate this in their assignments when a specific instruction has been provided, when the source-text indicates this, and only occasionally when the topic or the context may favour this. This is in keeping with the general use of the generic masculine in professional translation. Therefore, here we do not intend to blame students for not using inclusive language ${ }^{5}$. Rather, we would like to place this in a wider context: i.e. the marginal use of inclusive language in professional translation,

$4 \quad$ In this group, students translate either into Catalan or Spanish, as shown in the table.

5 By 'inclusive language' we refer to the use of words and expressions which do not exclude or discriminate against certain social groups (e.g. women, homosexual people, etc.). 
which is indeed a complex issue. This has been explored, amongst others, by Castro (2013), who has analysed "the ideological, poetic and economic pressures that (still) define the professional practice of translation". She has examined "the gap between the theory and practice of translation", and pointed at "a possible 'missing link' between feminist approaches to linguistics and to translation studies" (p. 35). That is, the feminist proposals to avoid sexism in language have not been applied in professional translation, as Castro (2013) and Bengoechea (2014) have shown. By the same token, we have identified a missing link between the research done in Translation Studies and its pedagogic implications. Therefore, with this study we try to bridge this gap as we address the problem of how to integrate the gender concerns which have been widely explored on a theoretical level with our pedagogic goals.

In the three groups, some students have translated "our children" as "my children", or even, in one case, as "my beloved children", a translation decision which is difficult to interpret. It could be following the fashion of the frequent collocation "my beloved friends", but might also be seen as the perception that children are under the responsibility -or protection- of the bride.

Group 1 - Advertising and Public Relations (UVic-UCC)

\begin{tabular}{lll}
\hline Friends/Children & Back translation & Percentage \\
\hline Amics & Friends & $100 \%$ \\
\hline Fills & Children & $83.40 \%$ \\
\hline Nens & Children & $16.60 \%$ \\
\hline Els nostres fills & Our children & $33.32 \%$ \\
\hline Els meus fills & My children & $49.98 \%$ \\
\hline Els meus fills estimats & My beloved children & $16,66 \%$ \\
\hline
\end{tabular}

Table 14. Analysis of the trans/ation of "Friends/Children". Group 1.

Group 2 - Master's London Metropolitan University

\begin{tabular}{|c|c|c|}
\hline Friends/Children & Back translation & Percentage \\
\hline moich przyjaciół i bliskich & $\begin{array}{l}\text { my friends and } \\
\text { closest ones }\end{array}$ & $20 \%$ \\
\hline $\begin{array}{l}\text { i miei amici e la mia } \\
\text { famiglia }\end{array}$ & $\begin{array}{l}\text { my friends and my } \\
\text { family }\end{array}$ & $20 \%$ \\
\hline 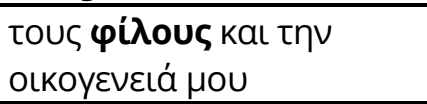 & $\begin{array}{l}\text { my friends and } \\
\text { family }\end{array}$ & $20 \%$ \\
\hline meus amigos e família & $\begin{array}{l}\text { my friends and } \\
\text { family }\end{array}$ & $20 \%$ \\
\hline
\end{tabular}

Table 15. Analysis of the translation of "Friends/Children". Group 2. 


\begin{tabular}{lll}
\hline Friends/Children & Back translation & Percentage \\
\hline mes amis et ma famille & $\begin{array}{l}\text { my friends and my } \\
\text { family }\end{array}$ & $20 \%$ \\
\hline our children & back translation & $20 \%$ \\
\hline naszych dzieci & our children & $20 \%$ \\
\hline nostri bambini & our children & $20 \%$ \\
\hline $\boldsymbol{\mu o u} \tau \omega \boldsymbol{T} \boldsymbol{\pi} \boldsymbol{\alpha} \boldsymbol{\delta} \boldsymbol{\delta} \boldsymbol{\omega} \boldsymbol{v}$ & my children & $20 \%$ \\
\hline nossos filhos & our children & $20 \%$ \\
\hline mes enfants & my children & $20 \%$ \\
\hline
\end{tabular}

Table 15 (cont.). Analysis of the trans/ation of "Friends/Children". Group 2.

Group 3 - Translation and Interpreting (UVic-UCC)

\begin{tabular}{lll}
\hline Friends/Children & Back translation & Percentage \\
\hline Amics & Friends & $100 \%$ \\
\hline Nostres fills / nuestros hijos & Our children & $93.75 \%$ \\
\hline Fills / hijos & Our children & $100 \%$ \\
\hline Els meus fills / mis hijos & Our children & $6.25 \%$ \\
\hline
\end{tabular}

Table 16. Analysis of the translation of "Friends/Children". Group 3.

Let us focus on the instruction to "Speak now" against domestic violence. In all groups, a "literal" translation has been combined with other translations, some of which emphasize the need to talk, and others, the call to action:

Group 1 - Advertising and Public Relations (UVic-UCC)

\begin{tabular}{lll}
\hline Speak now & Back translation & Percentage \\
\hline Parla ara & Speak now & $33.32 \%$ \\
\hline Parla-ho & Talk about it & $16.66 \%$ \\
\hline Explica-la. Decideix viure & $\begin{array}{l}\text { Explain it. Decide to } \\
\text { live }\end{array}$ & $16.66 \%$ \\
\hline Decideix no ser un més & $\begin{array}{l}\text { Decide not to be just } \\
\text { one more }\end{array}$ & $16.66 \%$ \\
\hline $\begin{array}{l}\text { Omission (no translation of } \\
\begin{array}{l}\text { Voice-over narration where } \\
\text { this is said) }\end{array}\end{array}$ & $16,66 \%$ \\
\hline
\end{tabular}

Table 17. Analysis of the translation of "speak now". Group 1.

As we can see in Group 1, there is more variation in the students' translation choices. This may be due to the fact that advertising professionals tend to be more creative and tend to act more freely when preparing an advertising campaign than 
advertising translators.

Group 2 - Master London Metropolitan University

\begin{tabular}{|c|c|c|}
\hline Speak now & Back translation & Percentage \\
\hline Parla adesso & Speak now & $20 \%$ \\
\hline 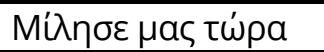 & Speak to us now & $20 \%$ \\
\hline Fale agora & Speak now & $20 \%$ \\
\hline Agissez maintenant & Act now & $20 \%$ \\
\hline Podziel się & Share & $20 \%$ \\
\hline
\end{tabular}

Table 18. Analysis of the translation of "speak now". Group 2.

Group 3 - Translation and Interpreting (UVic-UCC)

\begin{tabular}{lll}
\hline Speak now & Back translation & Percentage \\
\hline Parla ara & Speak now & $56.25 \%$ \\
\hline Parla & Speak & $12.50 \%$ \\
\hline Parleu-ne & Talk about it & $6.25 \%$ \\
\hline Actua & Act & $6.25 \%$ \\
\hline Rebel-la't & Rebel against it & $6.25 \%$ \\
\hline $\begin{array}{l}\text { Fes-te escoltar / hazte } \\
\text { escuchar }\end{array}$ & Speak up & $12.50 \%$ \\
\hline
\end{tabular}

Table 19. Analysis of the translation of "speak now". Group 3.

It is interesting to note that in Group 3 "Family Justice Center" has been replaced in 2 cases by Spanish real organizations against domestic violence, which shows the students' intention of targeting their translations for Spanish audiences.

Finally, it is worth mentioning that Group 3 translated this advertisement for dubbing. Therefore, students had to specify the sex of the narrator, so that the dubbing studio hires a male or a female actor for the voice-over. This was done by almost half of the students in Group 3 (43.75\%). We will see more about this in the following advertisements.

In the advertisement What Will You Feel, addressed to potential child sponsors, students have instinctively translated "boy" and "child" in most cases in the masculine when the images show boys. However, there are also cases in which neutral forms have been implemented. In the final off-screen female voice, we first see images of boys, while the narrator mentions "child". Towards the end of the ad, both boys and girls are shown, but this is only reflected in the Polish and Brazilian Portuguese translations, languages that have a generic word for "child". In the other translations, in all groups, the generic masculine is used. 


\begin{tabular}{ll}
\hline Boy & Back translation \\
\cline { 2 - 3 } Nen (Catalan) & Boy \\
\hline Chłopiec (Polish) & Boy \\
\cline { 2 - 3 } Ragazzo (Italian) & Boy \\
\cline { 2 - 3 } Niño (Spanish) & Boy \\
\cline { 2 - 3 } Menino (Brazilian Portuguese) & Child (little boy) \\
\hline Child & Back translation \\
\hline Nen (Catalan) & Boy \\
\hline bambino (Italian) & Child (little boy) \\
\hline Niño (Spanish) & Boy \\
\hline Dziecko (Polish) & Child (neuter) \\
\hline Dziecka (Polish) & Child (neuter/genitive) \\
\hline Criança (Brazilian Portuguese) & Child (neuter) \\
\hline
\end{tabular}

Table 20. Analysis of the translations of "boy" and "child".

As far as the term "sponsor" is concerned "You can become a World Vision child sponsor for just 60p a day"), it was occasionally translated in the masculine generic, although images show both men and women sponsors (e.g. "patrocinador" in Brazilian Portuguese and in Catalan, $16.6 \%$, and in Spanish, 10\%), and it is easy to find alternative inclusive formulations (e.g. turning the noun "sponsor" into a verb: "you can sponsor a child").

In Group 3, who translated the ad for dubbing, students have to indicate the sex of the characters in the ad, in order to provide an appropriate cast of female or male voice talent. In this sense, it is relevant to point out that the first sentence of the ad, "What is hope?", is uttered by a girl, but this is mostly not reflected in the dubbing script provided by students. In Group 3, 75\% of students incorrectly labeled the character a boy, not a girl.

Similarly, the off-screen voice of the narrator was identified as female in Group 3 by $37.5 \%$ of the students. Furthermore, there was not a clear correlation between identification of the girl on screen and the off-screen narrator on the part of the students. In Group 3 only $6.25 \%$ of students labeled both the character and the narrator in the feminine; whilst $56.25 \%$ used the generic masculine, and $37.50 \%$ either labeled the girl or the narrator incorrectly. These translations may indicate that students are so used to using/thinking in the masculine generic, that they use the masculine even when there are audiovisual clues showing female agency on screen, in an ad that generally fosters gender equality. We believe that this is due to their mind-set related to the values of their cultures.

The ad One water shows a relative balance between men (3) and women (2) who promote this campaign. Boys and girls are shown on screen collecting water, playing 
and going to school, and the final slogan is uttered by both girls and boys.

Students of all groups have translated people as generic (e.g. "personas"). With the exception of the Polish and Brazilian students who have used neutral forms, the others have all translated "children" in the generic masculine, and have not indicated that the final slogan is uttered by both boys and girls, which is especially relevant in the translation for dubbing.

\section{Conclusions}

From the present study, it can be inferred that the perception of responsibility towards gender issues is different in students of translation and in students of advertising. In our previous research, we found that students of translation have greater gender awareness related to commercial advertising than students of advertising. Here we have found that the same occurs when we work with non-profit advertising.

Most students (of translation and advertising) agree that advertising should not use sexist language. However, when we examine their translations (of commercials and non-profit advertising) we realise that it is difficult for them to avoid generic masculine choices in Romanic languages. This is consistent with the marginal use of inclusive language in professional contexts. But this gives linguistic and audiovisual invisibility to girls and women, which can have social consequences (for example, in translations for dubbing, if only male voices asking for water and for education are used). The use of inclusive language in audiovisual texts is a complex issue which deserves further attention in research. So far, De Marco (2012) is one of the few scholars who have addressed this issue in the context of audiovisual translation. Although her study is not entirely focused on inclusive language, her contrastive analysis about divergent perceptions of gender across different languages and cultures provides clues on the need and possibility to implement inclusive language in audiovisual communication on a wider scale.

The advert Domestic Violence is considered by most students to be 'stunning' (quoting their own words). By using this adjective they probably meant impressive, of high impact. They also added 'very emotional', 'explicit', 'brave' and 'clever'. However, it has also been described as "outrageous" and "a bit offensive". This can be compared with the negative emotional reactions often raised in social marketing in general (Hastings, Stead \& Webb, 2004) or in other sensitive issues, such as road safety (Lewis, Watson \& White, 2010). In the other two NP advertisements (One Water and What Will you Feel?), which are not explicitly gender-related, the students focus on the emotional charge that they bring and the useful, sensitising message they 
convey. Only a minority finds them pretentious and repetitive. In further studies, we will need to find analytic tools that allow students to explain the reactions the ads provoke in them as readers. We will also need to analyse this, in the light of current reception studies on emotion-based institutional advertising.

Students of advertising value the effectiveness of non-profit adverts rather than the perspective on gender. They do not see so many differences between the sensitiveness required for producing commercial and non-profit advertising. This is consistent with the current trend, in contemporary advertising, of hybridisation between non-profit and commercial advertising (Nos Aldás, 2007, discussed above).

Our research is aimed at making a contribution to the understanding of gender construction within and through the analysis and translation of non-profit advertising. At the same time, we believe that a gendered look at audiovisual texts can open avenues for future research into non-profit advertising.

\section{About the authors}

Montse Corrius Gimbert is a Senior Lecturer at the University of Vic-Central University of Catalonia (UVic-UCC), where she teaches English for specific purposes at undergraduate level and audiovisual translation at postgraduate level. She is member of the research group TRACTE (Audiovisual Translation, Communication and Place, SGR 2014, 565), where she leads the line of research on translation. Her main research interests include audiovisual translation (with a special focus on multilingual texts) as well as Advertising Translation, language learning and lexicography. She has published several articles and lectured on these areas of research. She is one of the authors of the Easy English Dictionary with a Catalan English-Vocabulary (2004).

Marcela De Marco is a Senior Lecturer in Translation at London Metropolitan University. She has long investigated the relationship between Audiovisual Translation and Gender Studies, which is at the heart of her research production. Her more recent publications include: 'The "engendering" approach in audiovisual translation' (2016, Target), the co-authored article 'Situated learning and situated knowledge: gender and translating audiovisual adverts' (2016, The Interpreter and Translator Trainer) and the monograph Audiovisual Translation through a Gender Lens (2012, Rodopi).

Eva Espasa Borrás is a Senior Lecturer at the University of Vic-Central University of Catalonia (UVic-UCC). She has published and lectured extensively on audiovisual 
translation, theatre translation, gender studies and translation training. Espasa is coordinator of the research group TRACTE (Audiovisual Translation, Communication and Place, SGR 2014, 565), and member of CEIG (Centre d'Estudis Interdisciplinaris de Gènere), both at UVic-UCC. She is member of the board of referees of Capsa de Pandora, a collection of books on gender studies of Eumo Editorial. She is a lecturer and member of coordination commission of the Official Master's Degree in Women, Gender and Citizenship Studies promoted by the Inter-University Women and Gender Studies Institute (IIEDG).

\section{Acknowledgements}

This research project was designed with our dearest colleague Francesca Bartrina (1968-2014), UVic-UCC, to whom we dedicate this article. She was a source of enthusiasm, inspiration and courage for us.

\section{LFE Article history}

Paper received: $20^{\text {ht }}$ July 2015

Paper received in revised form and accepted for publication: $1^{\text {st }}$ April 2016

\section{References}

Alvarado López, M. C. (2012). La publicidad en el marco de la comunicación para el desarrollo: hacia un Nuevo modelo de publicidad para el cambio social. Cuadernos de Información y Comunicación, 17, 191-207.

Álvarez Ruiz, A. (2003). Publicidad social: enfoques y métodos de análisis. In V. J. Benet \& E. Nos Aldás (Eds.), La publicidad en el tercer sector. Tendencias y perspectivas de la comunicación solidaria (pp. 129-142). Barcelona: Icaria.

Bartrina, F., Corrius, M., De Marco, M. \& Espasa, E. (2012). Evaluating students' gender commitment in the translation of audiovisual advertisements. I Congrés Internacional sobre investigació en didàctica de la traducció, Universitat Autònoma de Barcelona. DidTRAD-PACTE. 22 June 2012.

Bartrina, F. \& Espasa E. (2012). Evaluating creativity from a perspective of feminist pedagogies: Translating print advertisements in the virtual classroom". In M. Cánovas, G. 
Delgar, L. Keim, S. Khan \& A. Pinyana (Eds.), Challenges in language and translation teaching in the web 2.0.era (pp. 93-104). Granada: Comares.

Benet, V.J. (2003). El espectáculo solidario: La publicidad en el tercer sector y su proyección cultural. In V. J Benet \& E. Nos Aldás (Eds.), La publicidad en el tercer sector. Tendencias y perspectivas de la comunicación solidaria (pp. 15-51). Barcelona: Icaria.

Bengoechea, M. (2014). Feminist translation? No way! Spanish specialised translators' disinterest in feminist translation. Women's Studies International Forum, 42, 94-103.

Blizor, M. (2007). Employment in the US: Non-profits outpaces overall job growth. The JHU Gazette, 36(16). <http://pages.jh.edu/ gazette/2007/08jan07/08nonpr.html> [20-03-2015].

Burman, E. (1994). Poor children: charity appeals and ideologies of childhood. Changes: An International Journal of Psychology and Psychotherapy, 12(1), 29-36.

Burt, C. D. B. \& Strongman, K. (2005). Use of images in charity advertising: Improving donation and compliance rates". International Journal of Organisational Behavior, 8(8), 571580.

Cantera, L. M. (2002). La violencia doméstica. Lectora: Revista de Dones i Textualitat, 8 [monographic issue on gender violence coordinated by Francesca Bartrina], 71-77.

Castro, O. (2013). Talking at cross-purposes? The missing link between feminist linguistics and translation Studies. Gender and Language, 7(1), 35-58.

Chang, C. T. \& Lee, Y. K. (2009). The "I" of the beholder: The impacts of gender differences and self-referencing on charity advertising. In A. L. McGill \& S. Shavitt (Eds.), Advances in Consumer Research, 36 (pp. 748-749). Duluth, MN: Association for Consumer Research.

De Marco, M. (2012). Audiovisual Translation through a Gender Lens. Amsterdam \& New York: Rodopi.

De Marco, M. (2016). The "engendering" approach in AVT. Target: International Journal of Translation Studies. Special Issue: Audiovisual Translation. Theoretical and Methodological Challenges, 28(2), 314-325.

De Mooij, M. (2014a). Global Marketing and Advertising. Understanding Cultural Paradoxes. London: SAGE Publications.

De Mooij, M. (2014b). Human and Mediated Communication around the World. Cham, Heidelberg, New York, Dordrecht \& London: Springer.

García Pérez, R., Rebollo Catalán, M. A., Buzón García, O., González-Piñal, R., Barragán Sánchez, R. \& Ruiz Pinto, E. (2010). Actitudes del alumnado hacia la igualdad de género. Revista Ie Investigación Educativa, 28(1), 217-232. <http://revistas.um.es/rie/article/view/98951> [09-03-2015]. 
Gómez Ferri, J. (2003). Sensibilizando a los otros, solidarizándonos con ellos: la antropología en la intervención social solidaria. In V. J. Benet \& E. Nos Aldás (Eds.), La publicidad en el tercer sector. Tendencias y perspectivas de la comunicación solidaria (pp. 143-180). Barcelona: Icaria.

Hastings, G., Stead, M., \& Webb, J. (2004). Fear appeals in social marketing: Strategic and ethical reasons for concern. Psychology \& Marketing, 21(11), 961-986.

Hofstede, G. (2001). Culture's consequences. Comparing values, behaviors, institutions and organizations across nations. Thousand Oaks, CA: Sage Publications.

Laufer, D., Silvera, D. H., McBride, J. B. \& Schertzer, S. M. B. (2010). Communicating charity successes across cultures. Highlighting individual or collective achievement? European Journal of Marqueting, 44(9-10), 1322-1333.

Lewis, I. M., Watson, B., \& White, K. M. (2010). Response efficacy: The key to minimizing rejection and maximizing acceptance of emotion-based anti-speeding messages. Accident Analysis \& Prevention, 42(2), 459-467.

Nelson, M. R., Brunel, F. F., Supphellen, M. \& Manchada, R. V. (2006). Effects of culture, gender, and moral obligations on response to charity advertising across maculine and feminine cultures. Journal of Consumer Psychology, 16(1), 45-56.

Nos Aldás, E. (2007). Lenguaje publicitario y discursos solidarios. Barcelona: Icaria.

Pope, J., Sterrett, E. \& Asamoa-Tutu, F. (2013). Developing a marketing strategy for non-profit organizations: An exploratory study. Journal of Non-profit and Public Sector Marketing, 21(2), 184-201.

Rebollo-Catalán, M. A., García Pérez, R., Piedra, J., \& Vega, L. (2011). Diagnóstico de la cultura de género en educación: actitudes del profesorado hacia la igualdad. Revista de Educación, 355, 219-220.

Richards, R. (2004). An analysis of the representation of the third world in British charity advertisements. Australian \& New Zealand Communication Association: ANZCA04 $\begin{array}{lll}\text { Conference, Sydney, July } & 2004\end{array}$ <http://195.130.87.21:8080/dspace/bitstream/123456789/273/1/Richardsan\%20analysis\%20of\%20the\%20representation\%20of\%20the\%20third\%20worl.pdf> [12/07/2015]. 


\title{
Appendix
}

\section{Commercial advertisements' transcripts}

\author{
1) L'OREAL - KERRY WASHINGTON
}

http://www.youtube.com/watch?v=84SUfl8Yv4k

\begin{tabular}{l}
\hline L'Oreal - Kerry Washington \\
I feel most beautiful when I feel most empowered. For me feeling beautiful \\
is really about being in my body confidently and knowing that I'm worth it. \\
And that I don't have to shy away from who I am or what my gifts are. \\
Beauty comes from knowing who you are.
\end{tabular}

\section{2) L'OREAL - JENNIFER ANISTON}

https://www.youtube.com/watch?v=jGwc3ckxjNA

\begin{tabular}{|l|l|}
\hline \multicolumn{2}{|l|}{ L'Oreal. Jennifer Aniston } \\
\hline Jennifer & $\begin{array}{l}\text { So, what's the story? I've got a new relationship. A } \\
\text { new shampoo's taking a shine on me. }\end{array}$ \\
\hline Off-screen voice: & $\begin{array}{l}\text { New L'Oréal Elvive Multivitamins shampoo with } \\
\text { two times the vitamins. }\end{array}$ \\
\hline Jennifer: & $\begin{array}{l}\text { Shiny, glossy and manageable, just the way I like } \\
\text { it. Here comes the science of looking good. }\end{array}$ \\
\hline Off-screen voice: & $\begin{array}{l}\text { L'Oreal Elvive revitalizing shampoo has twice the } \\
\text { vitamins. Provitamin B5 penetrates the hair } \\
\text { helping to strengthen it from root to tip. }\end{array}$ \\
\hline Jennifer: & $\begin{array}{l}\text { My hair feels totally energized. Can't believe I just } \\
\text { said that. }\end{array}$ \\
\hline Off-screen voice & New L'Oreal Elvive Multivitamins shampoo. \\
\hline Jennifer: & $\begin{array}{l}\text { Trust me. It's from L'Oréal. I love it, and I'm worth } \\
\text { it! }\end{array}$ \\
\hline
\end{tabular}




\section{3) SECOND UN-MANLY THING}

https://www.youtube.com/watch?v=DAgiHrYSAv8

\begin{tabular}{|l|l|}
\hline \multicolumn{2}{|l|}{ Second Un-manly Thing } \\
\hline Man 1 & You didn't get a Miller Lite? \\
\hline Man 2 & No, what's the difference? \\
\hline Man 3 & Miller Lite has more taste! \\
\hline Man 2 & I don't care. I just got one of these. \\
\hline Man 1 & $\begin{array}{l}\text { Oh, that's the second unmanly thing you've done } \\
\text { today. }\end{array}$ \\
\hline Man 2 & What's the first? \\
\hline Man 2 & $\begin{array}{l}\text { Get me off this thing right now! Get me off this thing! } \\
\text { Get me off this thing! Yes, I guess that was unmanly. }\end{array}$ \\
\hline Off-screen voice & $\begin{array}{l}\text { Man up. Choose the light beer with most taste. Grab a } \\
\text { Miller Lite Vortex Bottle. Taste greatness. }\end{array}$ \\
\hline Man 3 & Hey, look! I made T-shirts! \\
\hline Man 1 & Awesome. \\
\hline
\end{tabular}

